\title{
Pengaruh Disiplin Kerja dan Motivasi Kerja Terhadap Kinerja Pegawai Pada SMK Tunas Jakasampurna
}

\author{
Muhammad Haedar ${ }^{1}$, Netti Natarida Marpaung ${ }^{2}$, Rini Ardista ${ }^{3}$ \\ ${ }^{1}$ Mahasiswa Prodi Manajemen, Sekolah Tinggi Ilmu Ekonomi Tribuana \\ ${ }^{2}$ Sekolah Tinggi Ilmu Ekonomi Tribuana \\ ${ }^{3}$ Sekolah Tinggi Ilmu Ekonomi Tribuana \\ mhaedar549@gmail.com
}

\begin{abstract}
This study aims to determine and analyze how much influence Work Discipline and Work Motivation have on Employee Performance at SMK Tunas Jakasampurna Bekasi City during the period September 2021 - January 2022. This study uses quantitative research which is research that aims to explain the relationship between two variables or more with a sample of 32 respondents. Data collection methods used are observation, interviews, questionnaires and documentaries. The data processing technique uses the help of the IBM SPSS version 26.0 application program so as to get the test results from the instrument test, classical assumption test, multiple linear regression test, determinant coefficient test and significant test ( $t$ test and $f$ test). The results showed that work discipline and work motivation had a positive influence on employee performance. Based on the test results the coefficient of determination is $28.8 \%$ while the remaining $71.2 \%$ is influenced by other variables that are not included in this research model. Based on the results of the t test (partial) and the results of the $f$ (simultaneous) test, it shows that there is a significant influence partially or simultaneously between the variables of work discipline and work motivation on employee performance.
\end{abstract}

Keyword: Work Discipline, Work Motivation, Employee Performance

\begin{abstract}
Abstrak
Penelitian ini bertujuan untuk mengetahui dan menganalisis seberapa besar pengaruh Disiplin Kerja dan Motivasi Kerja terhadap Kinerja Pegawai pada SMK Tunas Jakasampurna Kota Bekasi selama periode September 2021 - Januari 2022. Penelitian ini menggunakan penelitian kuantitatif yang merupakan penelitian yang bertujuan untuk menjelaskan hubungan antara dua variabel atau lebih dengan sampel berjumlah 32 responden. Metode pengumpulan data yang digunakan yaitu metode observasi, wawancara, kuesioner dan dokumenter. Teknik pengolahan data menggunakan bantuan program aplikasi IBM SPSS versi 26.0 sehingga mendapatkan hasil pengujian dari uji instrument, uji asumsi klasik, uji regresi linear berganda, uji koefisien determinan dan uji signifikan (Uji $t$ dan Uji f). Hasil penelitian menunjukkan bahwa Disiplin Kerja dan Motivasi Kerja mempunyai pengaruh yang positif terhadap Kinerja Pegawai. Berdasarkan hasil uji koefisien determinasi sebesar 28,8\% sedangkan sisanya 71,2\% dipengaruhi oleh variabel lain yang tidak dimasukan dalam model penelitian ini. Berdasarkan hasil uji $t$ (parsial) dan hasil uji $f$ (simultan) menunjukkan bahwa terdapat adanya pengaruh yang signifikan secara parsial maupun simultan antara variabel disiplin kerja dan motivasi kerja terhadap kinerja pegawai.
\end{abstract}

\section{Kata Kunci : Disiplin Kerja, Motivasi Kerja, Kinerja Pegawai}

\section{PENDAHULUAN}

Sumber daya manusia merupakan salah satu aset terpenting bagi kemajuan dan perkembangan perusahaan. Oleh karena itu agar sumber daya manusia dapat menjadi masukan yang akan memberikan hasil yang optimal bagi organisasi maupun perusahaan, maka diperlukan suatu manajemen dan setiap tugas akan dapat berhasil dengan baik tergantung dari sumber daya manusia itu sendiri sebagai pelaksana kegiatan dalam 
suatu perusahaan. Menyadari pentingnya sumber daya manusia, sebuah perusahaan harus memperhatikan kebutuhan yang berbeda dari setiap pegawai. Karena pegawai pada dasarnya merupakan penggerak utama dalam segala aktivitas perusahaan. Perusahaan yang sedang berkembang akan selalu memikirkan pekerjaan yang efektif dan efisien agar mudah dikontrol dan dinilai sehingga memudahkan dalam mendefinisikan kinerja pegawai.

Kinerja pegawai merupakan faktor yang penting dalam suatu perusahaan. Hal yang mempengaruhi kinerja pegawai salah satunya adalah disiplin kerja dan motivasi kerja, dalam meningkatkan kinerja dan meningkatkan keterampilan dan kemampuan pegawai sejalan dengan kemajuan teknologi untuk menjadi kompeten dalam bekerja dan membantu kinerja pegawai operasional perusahaan. Kinerja pegawai merupakan faktor penting bagi keberlangsungan hidup perusahaan yang menjadi sebuah keharusan bagi perusahaan untuk menciptakan sumber daya manusia yang mampu menghasilkan kinerja optimal untuk mencapai tujuan perusahaan maupun organisasi Untuk menentukan kinerja yang optimal diperlukannya disiplin kerja dan motivasi kerja yang baik dimana kegiatan tersebut diberikan karena pada dasarnya pegawai yang bekerja terdiri dari orang-orang yang berbeda latar belakang pendidikan, status sosial ekonomi dan sebagainya yang pada akhirnya akan bekerja sama. dalam lingkungan kerja yang sama.

Faktor lain yang dapat mendukung kinerja pegawai adalah Disiplin Kerja. Disiplin kerja merupakan wujud kepatuhan terhadap aturan kerja dan juga tanggung jawab pribadi pegawai terhadap perusahaan. Disiplin pegawai memegang peranan yang sangat penting dalam pelaksanaan tugasnya sehari-hari. Seorang pekerja yang mempunyai tingkat kedisiplinan yang tinggi akan selalu bekerja dengan baik walaupun tanpa diawasi oleh atasan. Seorang pegawai yang disiplin tidak akan melakukan halhal lain yang tidak ada hubungannya dengan pekerjaan. Selain itu, pekerja yang mempunyai kedisiplinan akan mentaati peraturan yang ada di lingkungan kerja dengan kesadaran yang tinggi tanpa adanya sebuah paksaan. Dengan demikian pegawai yang disiplin akan memiliki kinerja yang baik dibandingkan dengan pegawai yang malas karena waktu kerja digunakan untuk melaksanakan pekerjaan sesuai dengan target. Kesimpulannya, pegawai sekolah tunas jakasampurna sulit untuk produktif, berkembang dan meningkatkan kinerjanya sesuai dengan 
motivasi dan pengalaman kerja pada khususnya. Selain itu, juga sulit untuk menciptakan dan mencapai tujuan organisasi yang optimal secara umum.

Faktor lain yang dapat mempengaruhi kinerja pegawai selain disiplin kerja adalah motivasi kerja. Motivasi merupakan salah satu indikator yang mempengaruhi kualitas sumber daya manusia. Oleh karena itu, motivasi yang tinggi sangat dipengaruhi oleh keberadaan pemimpin yang mampu memotivasi pegawai. Pegawai tidak hanya bekerja secara formal di kantor tetapi juga dapat merasakan dan menikmati pekerjaan tersebut. Oleh karena itu, ia tidak akan merasa bosan dan akan bekerja lebih rajin. Pada dasarnya motivasi dapat membuat pegawai bekerja keras sehingga pegawai mampu menghasilkan pencapaian suatu tujuannya. Hal ini akan meningkatkan produktivitas karyawan yang berdampak pada pencapaian tujuan organisasi.

Berdasarkan observasi awal yang telah dilakukan peneliti pada pegawai SMK Tunas Jakasampurna, terlihat kinerja yang dihasilkan pegawai sudah cukup baik namun belum maksimal, dimana masih adanya beberapa masalah yang dapat mempengaruhi kinerja pegawai. Adapun masalah yang ditemukan pada kinerja pegawai seperti kurangnya tanggung jawab, kemampuan untuk bekerja sama, dan ketepatan waktu dalam menyelesaikan suatu pekerjaan. Pada sisi disiplin kerjanya, terdapat kehadiran yang kurang tepat waktu dan pulang lebih cepat yang dilakukan oleh sejumlah guru dan pegawai. Dampaknya, banyak sekali pekerjaan yang terabaikan dan tidak dapat menyelesaikan pekerjaannya tepat waktu, dan untuk kualitas pekerjaannya yang kurang maksimal serta banyaknya tenaga pendidik yang terlambat masuk kelas untuk mengajar. Sedangkan permasalahan pada motivasi ditemukan adanya ketimpangan gaji yang diberikan seperti keterlambatan dalam penggajian sehingga dapat mempengaruhi semangat kerja para pegawai.

\section{Disiplin Kerja}

Menurut Sastrohardiwiryo dalam Alimah (2020 : 61) menyatakan Disiplin merupakan suatu sikap menghormati, menghargai, patuh dan taat terhadap peraturan-peraturan yang berlaku, baik yang tertulis maupun yang tidak tertulis serta sanggup menjalankannya dan tidak mengelak untuk menerima sanksisanksinya apabila ia melanggar tugas dan wewenang yang diberikan kepadanya.

Menurut Sutrisno dalam Tanjung dan Manalu (2019 : 343) menyimpulkan bahwa disiplin kerja adalah perilaku 
seseorang yang sesuai dengan peraturan, prosedur kerja yang ada atau disiplin adalah sikap, tingkah laku, dan perbuatan yang sesuai dengan peraturan dari organisasi baik tertulis maupun yang tidak tertulis.

Dari berbagai pengertian diatas dapat diambil kesimpulannya bahwa kedisiplinan merupakan sebuah kesadaran dan kesediaan bagi seseorang yang mentaati semua peraturan-peraturan yang telah dibuat oleh perusahaan serta normanorma sosial yang berlaku dan bila melanggarnya akan ada sanksi atas pelanggarannya

Menurut Veithzal Rivai dalam Sinambela (2016 : 355-356) disiplin kerja mempunyai beberapa indikator yaitu :

a. Kehadiran.

Kehadiran merupakan salah satu indikator yang sangat mendasar dalam mengukur tingkat kedisiplinan. Dan biasanya pegawai yang memiliki tingkat kedisiplinan kerja nya rendah selalu terbiasa untuk terlambat dalam pekerjaannya.

b. Ketaatan pada peraturan kerja.

Pegawai yang selalu taat serta mematuhi pada setiap peraturan kerja tidak akan melalaikan prosedur kerja dan akan selalu mengikuti arahan dan pedoman kerja yang telah ditetapkan oleh perusahaan. c. Ketaatan pada standar kerja.

Pegawai yang selalu taat pada standar kerjanya akan melalui besarnya tanggung jawab yang diberikan kepada pegawai terhadap tugas yang telah diamanahkan kepadanya.

d. Tingkat kewaspadaan tinggi.

Pegawai yang mempunyai kewaspadaan yang tinggi akan selalu berhati-hati dalam bekerja dengan penuh perhitungan dan ketelitian, serta selalu menggunakan sesuatu secara efektif dan efisien dalam bekerja.

e. Bekerja etis.

Beberapa pegawai mungkin melakukan sebuah tindakan yang tidak sopan terhadap customer atau terlibat dalam tindakan yang tidak pantas untuk dilihat dan dilakukan. Hal ini merupakan sebuah bentuk tindakan dari orang yang tidak disiplin sehingga bekerja etis merupakan salah satu wujud dari disiplin kerja pegawai.

\section{Motivasi Kerja}

Motivasi berasal dari bahasa latin movere, yang berarti menggerakkan (to move). Menurut Mathis dan Jackson dalam Ajabar \& Marina (2019 : 81) "Motivasi adalah keinginan dalam diri seseorang yang menyebabkan orang tersebut bertindak". Berdasarkan pengertian motivasi tersebut maka motivasi dapat diartikan sebagai suatu 
cara dalam mendorong gairah kerja pegawai, agar mereka mau berkerja keras dengan mengerakkan seluruh kemampuan dan keterampilan yang dimilikinya untuk mewujudkan tujuan organisasi

Sedangkan menurut Fadhil dan Mayowan dalam Sitio (2019 : 72) Motivasi kerja adalah kesediaan untuk mengeluarkan tingkat upaya yang tinggi untuk tujuan organisasi yang di kondisikan oleh kemampuan upaya itu dalam memenuhi beberapa kebutuhan individual.

Dari pengertian diatas, terlihat bahwa motivasi berhubungan dengan kekuatan dan dorongan yang ada dalam diri manusia. Meski motivasi tidak terlihat dari luar dan yang terlihat hanyalah tingkah laku manusia saja tapi hal ini dapat menjadi pendorong seseorang untuk mencapai tujuan tertentu karena tingkah laku tersebut dilandasi berbagai macam motivasi. Jadi, motivasi adalah suatu kekuatan pada diri seseorang maupun faktor dari sebuah organisasi yang mendorong atau menggerakkan untuk mencapai suatu tujuan tertentu.

Adapaun indikator motivasi kerja Menurut Mangkunegara dalam Busro (2018 : 56-57) Teori Abraham Maslow mengemukakan bahwa ada 5 kebutuhan manusia antara lain: a. Kebutuhan fisiologis

Kebutuhan sesuatu yang diperlukan manusia untuk makan, minum, perlindungan fisik, bernapas dan seksual. Kebutuhan ini merupakan kebutuhan paling mendasar atau juga disebut sebagai kebutuhan tingkat yang paling bawah/terendah. Dengan kata lain, kebutuhan fisiologis yaitu kebutuhan akan makanan, minuman, tempat tinggal, dan bebas dari rasa sakit.

b. Kebutuhan rasa aman

Kebutuhan sesuatu akan perlindungan diri dari berbgai ancaman, bahaya, dan pertentangan serta dari lingkungan hidup itu sendiri. Jadi, kebutuhan keamanan dan keselamatan, yaitu kebutuhan untuk bebas dari ancaman (aman dari peristiwa atau lingkungan yang mengancam),

c. Kebutuhan kebersamaan, sosial, dan cinta

Yaitu kebutuhan akan pertemanan, afiliasi, interaksi, dan cinta. Jadi, Kebutuhan untuk rasa memiliki atau disebut sosial ini yaitu kebutuhan yang dapat diterima oleh kelompok, berafiliasi, berinteraksi, dan kebutuhan untuk mencintai dan dicintai.

d. Kebutuhan akan harga diri

Kebutuhan yang diperlukan oleh seseorang untuk merasakan bahwa dirinya merupakan orang yang patut untuk 
dihargi dan dihormati oleh orang lain. Jadi, kebutuhan harga diri merupakan suatu kebutuhan akan harga diri dan rasa hormat dari orang lain.

e. Kebutuhan aktualisasi diri

Yaitu suatu kebutuhan untuk bisa dapat memenuhi diri sendiri secara maksimal dengan menggunakan kemampuan, keterampilan, dan potensi. Kebutuhan ini merupakan kebutuhan tingkat yang paling tinggi dan untuk berpendapat dengan mengemukakan ideide, gagasan, dan kritik terhadap sesuatu.

\section{Kinerja Pegawai}

Menurut Mangkunegara dalam Aini dan Ariefiantoro (2018 : 143) Kinerja berasal dari kata Job Performance atau Actual Performance (prestasi kerja atau prestasi kerja yang dicapai oleh seseorang). Pengertian kinerja adalah hasil kerja secara kualitas dan kuantitas yang dicapai seseorang karyawan dalam melaksanakan tugasnya sesuai tanggung jawab yang diberikan. Selain itu, kinerja juga dapat diartikan sebagai suatu hasil dan usaha karyawan yang dicapai dengan adanya kemampuan dan perbuatan dalam situasi tertentu.

Menurut Prawirosentono dalam Sinambela (2016 : 481) Kinerja adalah hasil kerja yang dapat dicapai oleh seseorang atau sekelompok orang dalam suatu organisasi, sesuai dengan wewenang dan tanggung jawab masingmasing, dalam rangka upaya mencapai tujuan organisasi bersang kutan secara legal, tidak melanggar hukum dan sesuai dengan moral dan etika.

Dari berbagai pengertian para ahli diatas dapat diambil kesimpulan bahwa kinerja pegawai adalah suatu hasil atau prestasi kerja pegawai yang dapat dinilai dari segi kualitas maupun kuantitasnya berdasarkan standar kerja yang ditentukan oleh pihak organisasi.

Menurut Robbins dalam Ranu (2016:69) mengemukakan ada lima Indikator untuk mengukur suatu kinerja pegawai secara individu, yaitu:

\section{a. Kualitas}

Kualitas kerja seseorang dapat diukur dari kualitas kerja yang dihasilkan dan kesempurnaan pekerjaannya yang telah diberikan tugas kepadanya terhadap keterampilan dan kemampuan dari pegawai itu sendiri.

\section{b. Kuantitas}

Kuantitas kerja seseorang dapat diukur dari berapa banyak atau jumlah yang telah dihasilkan pegawai dan dinyatakan dalam istilah ini seperti berapa banyak nya jumlah unit, jumlah siklus aktivitas yang diselesaikan.

c. Ketepatan waktu

Ketepatan waktu bagi pekerja dapat diukur dari tingkat aktivitas pekerja yang 
diselesaikan pada awal waktu yang dinyatakan, dilihat dari sudut koordinasi dengan hasil output serta memaksimalkan waktu yang tersedia untuk aktivitas lain.

\section{d. Efektivitas}

Efektivitas dapat diukur dari tingkat penggunaan sumber daya organisasinya yang terdiri dari tenaga, tekonologi, uang, serta bahan baku yang dimaksimalkan dengan maksud untuk menaikkan hasil dari setiap unit dalam penggunaan sumber daya.

e. Kemandirian

Kemandirian dapat diukur dari tingkat seorang pegawai yang mana nantinya akan dapat menjalankan fungsi kerjanya untuk komitmen dalam bekerja atau dari tingkat dimana pegawai mempunyai sebuah komitmen kerja dengan instansi dan tanggung jawab pegawai terhadap perusahaan (Marpaung, 2021a).

\section{METODE PENELITIAN}

Penelitian ini dilakukan pada SMK Tunas Jakasampurna Pada sekolah ini ditemukan permasalahan yang berkaitan dengan kinerja pegawai. Oleh sebab itu, objek penelitian ini dilakukan untuk mengetahui kinerja pegawai melalui disiplin kerja dan motivasi kerja.

Penelitian ini menggunakan metode penelitian kuantitatif yang merupakan penelitian yang bertujuan untuk menjelaskan hubungan antara dua variabel atau lebih. Penelitian ini menggunakan instrumen penelitian berupa pedoman wawancara, pedoman angket dan pedoman dokumentasi untuk memperoleh data mengenai pendidikan dan pelatihan serta kinerja pegawai (Marpaung, 2021b). Dalam penelitian ini populasi yang diambil adalah keseluruhan pegawai yang ada di SMK Tunas Jakasampurna sebanyak 32 orang pegawai dengan menggunakan teknik sampling jenuh.

\section{HASIL DAN PEMBAHASAN}

Sebelum melakukan pengujian hipotesis, terlebih dahulu akan dilakukan pengujian terjadinya penyimpangan terhadap asumsi klasik dengan menggunakan bantuan Program SPSS versi 26.0. Dalam asumsi klasik terdapat beberapa pengujian yang harus dilakukan, yakni Uji Normalitas, Uji Multikoliniearitas, Uji Heteroskedasitas.

\section{Uji Normalitas}

Model regresi yang baik adalah memiliki distribusi data normal atau mendekati normal. Uji normalitas data anatara lain dapat dilakukan dengan membandingkan probilitas nilai Kolmogorov-Smirnov dengan sebesar 0,05 (5\%). Apabila probilitas nilai 
koefisien $\alpha>0,05$ maka dapat terdistribusi normal, sebaliknya jika nilai koefisien $<0,05$ maka tidak dapat terdistribusi normal. Uji normalitas yang digunakan dalam penelitian ini yaitu menggunakan analisis grafik histogram dan grafik P-Plot.

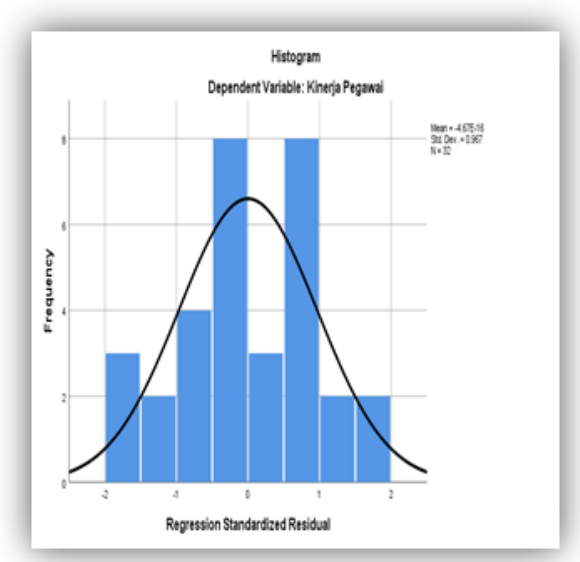

Sumber Data : Output SPSS V.26 yang diolah, 2022

Gambar 4.1. Hasil Uji Normalitas (Grafik Histogram)

Berdasarkan gambar 4.1 grafik histogram diatas, terlihat residual terdistribusi normal dan simetris serta tidak begitu cenderung ke kiri ataupun kekanan.

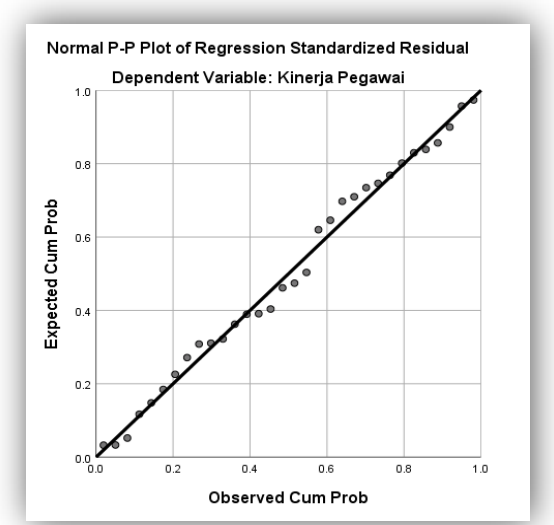

Sumber Data : Output SPSS V.26 yang diolah, 2022

Gambar 4.2

Hasil Uji Normalitas (Grafik P-Plot)
Berdasarkan gambar 4.2 grafik Normal Probability P-Plot diatas, dapat diketahui bahwa sebaran titik-titik data residual disekitar mendekati garis diagonal, maka dapat diartikan bahwa data yang diteliti berdistribusi normal.

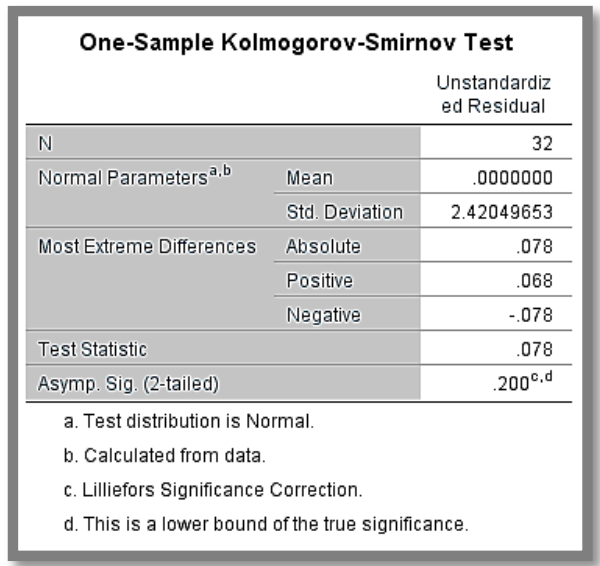

Sumber Data : Output SPSS V.26 yang diolah, 2022

Gambar 4.3

One-Sample Kolmogorov-Smirnov Test

Berdasarkan Gambar 4.3 di atas, diketahui bahwa nilai Asymp.Sig. (2tailed) sebesar 0,200 >0,05. Maka sesuai dengan dasar pengambilan keputusan dalam uji normalitas One-Sample Kolmogorov-Smirnov di atas, Apabila probilitas nilai koefisien $\alpha>0,05$ maka dapat terdistribusi normal, sebaliknya jika nilai koefisien $<0,05$ maka tidak dapat terdistribusi normal. Dapat disimpulkan bahwa hasil data diatas tersebut dinyatakan berdistribusi normal. Dengan demikian asumsi atau persyaratan normalitas dalam model regresi sudah terpenuhi. 


\section{Uji Multikolinieritas}

Multikoliniearitas terjadi jika ada hubungan linear yang sempurna atau hampir sempurna, antara beberapa atau semua variabel independent dalam model regresi. Uji multikoliniearitas bertujuan untuk menguji apakah model regresi ditemukan adanya korelasi antara variabel bebas (independent). Model regresi yang baik seharusnya tidak terjadi korelasi antara variabel bebas. Untuk menguji adanya multikoliniearitas dapat dilakukan dengan menganalisis korelasi antara variabel dan perhitungan jika nilai VIF (Variance Inflation Factor) dibawah atau $<10$ dan nilai tolerance value diatas $>0,1$ maka tidak terjadi multikolinieritas.

Tabel 4.1

Hasil Uji Multikolinieritas

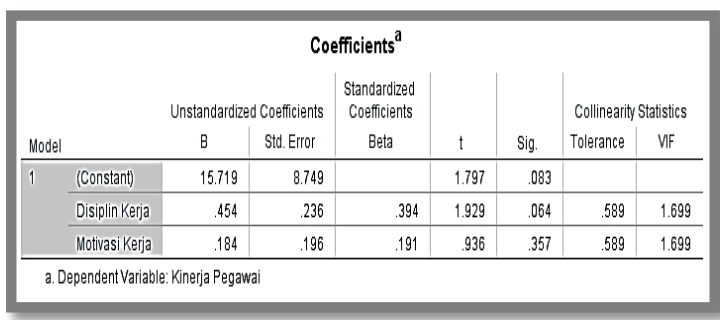

Sumber Data : Output SPSS V.26 yang diolah, 2022

Berdasarkan tabel 4.4 hasil pengujian multikolinearitas diatas, menunjukan bahwa nilai VIF (Variance Inflation Factor) dari variabel Disiplin Kerja $\left(\mathrm{X}_{1}\right)$ dan Motivasi Kerja $\left(\mathrm{X}_{2}\right)$ sebesar $1.699<10$ dan nilai tolerance value dari variabel Disiplin Kerja $\left(\mathrm{X}_{1}\right)$ dan Motivasi Kerja $\left(\mathrm{X}_{2}\right)$ sebesar $589>$ 0,1 . Dapat disimpulkan bahwa hasil data diatas tersebut dinyatakan tidak terjadi multikolinieritas. Dengan demikian asumsi atau persyaratan uji multikolinieritas dalam model regresi sudah terpenuhi.

\section{Uji Heteroskedastisitas}

Uji heteroskedastisitas bertujuan untuk menguji apakah dalam model regresi terdapat ketidaksamaan varians dari residual satu pengamatan ke pengamatan lainnya. Jika varians dan residual dari satu pengamatan ke pengamatan lain tetap, maka disebut homoskedastisitas. Untuk mendeteksi ada tidaknya heteroskedastisitas, Anda dapat melihat grafik plot, termasuk nilai prediksi variabel dependen (ZPRED) dan residualnya (SRESID). Jika tidak ada pola yang jelas, dan titik-titik menyebar di atas dan di bawah angka 0 pada sumbu $\mathrm{Y}$, maka tidak terjadi heteroskedastisitas.

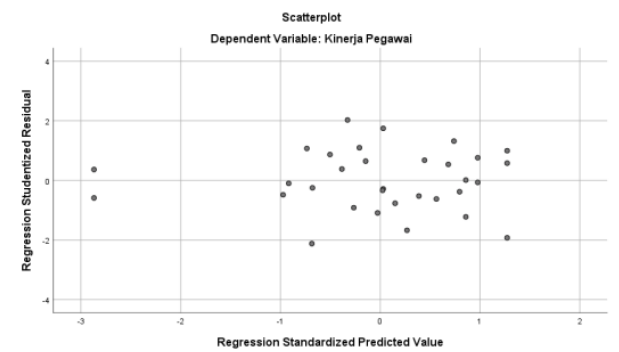

Sumber Data : Output SPSS V.26 yang diolah, 2022

\section{Gambar 4.4}

Hasil Uji Heteroskedastisitas 
Berdasarkan gambar 4.4 hasil uji heteroskedastisitas diatas, terlihat titiktitik tersebar secara acak pada sumbu $\mathrm{X}$ maupun sumbu Y dan tidak membentuk suatu pola maka model regresi dalam penelitian ini dinyatakan tidak terjadi heteroskedastisitas dan layak untuk digunakan.

\section{Analisis Regresi Linear Berganda}

Analisis regresi berganda merupakan alat yang digunakan untuk mengetahui pengaruh antara variabel independent (X) terhadap variabel dependent (Y). Analisis data yang digunakan adalah analisa kuantitatif yaitu dengan suatu model untuk mengukur pengaruh disiplin kerja dan motivasi kerja terhadap kinerja pegawai digunakan perhitungan regresi linear berganda. Untuk pengujian dianggap kinerja pegawai (Y) dipengaruhi oleh disiplin kerja $\left(\mathrm{X}_{1}\right)$ dan motivasi kerja $\left(\mathrm{X}_{2}\right)$. Disini dapat kita masukan ke dalam fungsi linier sederhana dengan bentuk persamaan, (Ghozali, 2005:82). Rumus yang digunakan :

$$
Y=\alpha+\beta_{1} X_{1}+\beta_{2} X_{2}
$$

Dimana:

$$
\begin{array}{ll}
\alpha & =\text { Kostanta } \\
\mathrm{Y} & =\text { Kinerja Pegawai } \\
\mathrm{X}_{1} & =\text { DisplinKerja } \\
\mathrm{X}_{2} & =\text { Motivasi Kerja } \\
\beta & =\text { Parameter atau koefisien regresi }
\end{array}
$$

Gambar 4.2

Hasil Regresi Linear Berganda

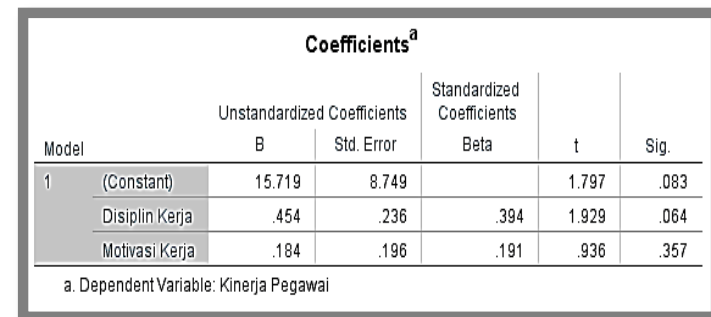

Sumber Data : Output SPSS V.26 yang diolah, 2022

Berdasarkan rumus yang digunakan $\mathrm{Y}=\alpha+\beta_{1} \mathrm{X}_{1}+\beta_{2} \mathrm{X}_{2}=15.719+0,454+$ 0,184 , dengan arti :

1. Nilai $\alpha$ sebesar 15.719 merupakan konstanta atau keadaan saat variabel kinerja pegawai (Y) belum dipengaruhi oleh variabel lainnya yaitu variabel disiplin kerja $\left(\mathrm{X}_{1}\right)$ dan variabel motivasi kerja $\left(\mathrm{X}_{2}\right)$. Jika variabel independent tidak ada maka variabel kinerja pegawai tidak mengalami perubahan.

2. Nilai $\beta_{1}$ (koefisien regresi $X_{1}$ ) sebesar 0,454. Hal ini menunjukkan bahwa variabel disiplin kerja mempunyai pengaruh yang positif terhadap kinerja pegawai yang berarti bahwa setiap kenaikan satu satuan variabel disiplin kerja maka akan mempengaruhi kinerja pegawai sebesar 0,454. Dengan asumsi bahwa variabel lain tidak diteliti dalam penelitian ini.

3. Nilai $\beta_{2}$ (koefisien regresi $\mathrm{X}_{2}$ ) sebesar 0,184. Hal ini menunjukkan bahwa 
variabel motivasi kerja mempunyai pengaruh yang positif terhadap kinerja pegawai yang berarti bahwa setiap kenaikan satu satuan variabel motivasi kerja maka akan mempengaruhi kinerja pegawai sebesar 0,184. Dengan asumsi bahwa variabel lain tidak diteliti dalam penelitian ini.

\section{Koefisien Determinan}

Koefisien determinan $\left(\mathrm{R}^{2}\right)$ dimaksudkan untuk mengetahui tingkat ketepatan paling baik dalam analisis regresi, dimana hal yang ditunjukan oleh besarnya koefisien determinan $\left(\mathrm{R}^{2}\right)$ antara 0 (nol) dan 1 (satu). Koefisien determinasi $\left(\mathrm{R}^{2}\right)$ nol variabel independent sama sekali tidak berpengaruh terhadap variabel dependent. Apabila koefisien determinasi semakin mendekati satu, dapat dikatakan bahwa variabel independent berpengaruh terhadap variabel dependent. Selain itu, koefisien determinasi dipergunakan untuk mengetahui persentase perubahan variabel terikat (Y) yang disebabkan oleh variabel (X).

Tabel 4.3

Hasil Koefisien Determinan

\begin{tabular}{ll|r|c|r}
\multicolumn{8}{c}{ Model Summary } \\
Model & $\mathrm{R}$ & $\mathrm{R}$ Square & $\begin{array}{c}\text { Adjusted R } \\
\text { Square }\end{array}$ & $\begin{array}{c}\text { Std. Error of } \\
\text { the Estimate }\end{array}$ \\
\hline 1 & $.537^{\mathrm{a}}$ & .288 & .239 & 2.503 \\
\hline \multicolumn{2}{r}{ a. Predictors: (Constant), Motivasi Kerja, Disiplin Kerja }
\end{tabular}

Sumber Data : Output SPSS V.26 yang diolah, 2022
Berdasarkan tabel 4.7 dipengaruhi nilai koefisien $\mathrm{R}_{\text {Square }}\left(\mathrm{R}^{2}\right)$ sebesar 0,288 atau 28,8\%. Hal ini menunjukan bahwa besarnya pengaruh variabel independent Disiplin Kerja dan Motivasi Kerja terhadap variabel dependent Kinerja Pegawai sebesar 28,8\%. Sedangkan sisanya $71,2 \%$ dipengaruhi oleh variabel lain yang tidak dimasukan dalam model penelitian ini.

\section{Uji t (Parsial)}

Uji t digunakan untuk menguji signifikansi variasi hubungan antara variabel $\mathrm{X}$ dan $\mathrm{Y}$. Dalam penelitian ini untuk menguji apakah variabel $X_{1}$ dan $X_{2}$ secara parsial benar-benar berpengaruh secara parsial terhadap variabel dependent. Dengan nilai signifikansi < 0,05 dan nilai $t_{\text {hitung }}>$ nilai $t_{\text {tabel }}$.

Tabel 4.4

Hasil Uji t Disiplin Kerja

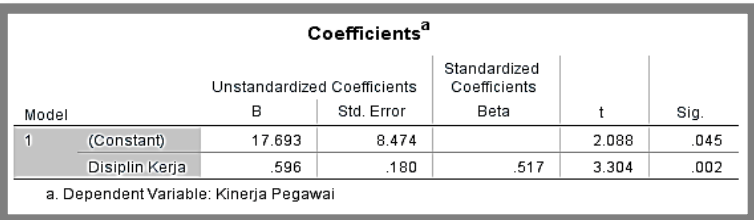

Sumber Data : Output SPSS V.26 yang diolah, 2022

Berdasarkan tabel 4.8 hasil uji $\mathrm{t}$ (parsial) diatas, menunjukkan bahwa nilai signifikansi pengaruh disiplin kerja $\left(\mathrm{X}_{1}\right)$ terhadap kinerja pegawai (Y) adalah $0,002<0,05$ dan nilai $t_{\text {hitung }} 3.304>$ nilai $t_{\text {tabel }}$ 2.045, maka $\mathrm{H}_{\mathrm{o}} 1$ di tolak dan $\mathrm{H}_{\mathrm{a}} 1$ diterima. Sehingga dapat diartikan bahwa 
terdapat pengaruh disiplin kerja terhadap kinerja pegawai secara signifikansi.

Tabel 4.5

Hasil Uji t Motivasi Kerja

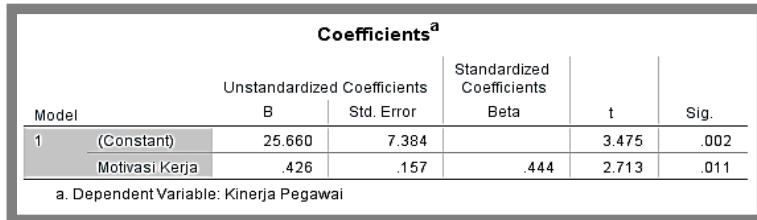

Sumber Data : Output SPSS V.26 yang diolah, 2022

Berdasarkan tabel 4.5 hasil uji $\mathrm{t}$ (parsial) diatas, menunjukkan bahwa nilai signifikansi pengaruh motivasi kerja $\left(\mathrm{X}_{2}\right)$ terhadap kinerja pegawai (Y) adalah $0,011<0,05$ dan nilai $t_{\text {hitung }} 2.713>$ nilai $t_{\text {tabel }}$ 2.045, maka $\mathrm{H}_{0} 2$ di tolak dan $\mathrm{H}_{\mathrm{a}} 2$ diterima. Sehingga dapat diartikan bahwa terdapat pengaruh motivasi kerja terhadap kinerja pegawai secara signifikansi.

\section{Uji f (Simultan)}

Pengujian hipotesis simultan (Uji f) bertujuan untuk mengetahui pengaruh secara bersama-sama variabel independent terhadap variabel dependent. Dalam penelitian ini untuk menguji apakah variabel $X_{1}$ dan $X_{2}$ secara bersama-sama benar-benar berpengaruh secara parsial terhadap variabel dependent dengan nilai signifikansi $<0,05$ dan nilai $\mathrm{f}_{\text {hitung }}>$ nilai $\mathrm{f}_{\text {tabel }}$.

\section{Tabel 4.6}

Hasil Uji $f$

\begin{tabular}{|c|c|c|c|c|c|c|}
\hline \multicolumn{7}{|c|}{ ANOVA $^{a}$} \\
\hline Model & & $\begin{array}{l}\text { Sum of } \\
\text { Squares }\end{array}$ & df & Mean Square & $\mathrm{F}$ & Sig. \\
\hline \multirow[t]{3}{*}{1} & Regression & 73.596 & 2 & 36.798 & 5.876 & $.007^{\mathrm{b}}$ \\
\hline & Residual & 181.623 & 29 & 6.263 & & \\
\hline & Total & 255.219 & 31 & & & \\
\hline
\end{tabular}

Berdasarkan tabel 4.10 hasil uji $\mathrm{f}$ (Simultan) diatas, dapat diketahui nilai signifikansi untuk pengaruh disiplin kerja $\left(\mathrm{X}_{1}\right)$ dan Motivasi Kerja $\left(\mathrm{X}_{2}\right)$ terhadap kinerja pegawai (Y) adalah sebesar 0,007 $<0,05$ dan $\mathrm{f}_{\text {hitung }}$ sebesar $5.876>$ nilai $\mathrm{f}_{\text {tabel }}$ 3.328. Hal tersebut membuktikan bahwa $\mathrm{H}_{\mathrm{o}} 3$ di tolak dan $\mathrm{H}_{\mathrm{a}} 3$ diterima, sehingga dapat diartikan bahwa pengaruh disiplin kerja $\left(\mathrm{X}_{1}\right)$ dan Motivasi Kerja $\left(\mathrm{X}_{2}\right)$ terhadap kinerja pegawai $(\mathrm{Y})$ secara signifikansi.

\section{Pembahasan}

\section{Pengaruh Disiplin Kerja Terhadap} Kinerja Pegawai

Hasil pengujian hipotesis secara parsial disiplin kerja memiliki pengaruh terhadap kinerja pegawai, dan dapat dilihat pada rangkuman hasil pengujian dengan analisis uji $\mathrm{t}$ (parsial) yang diuraikan dalam tabel 4.16 yang menunjukkan bahwa hipotesis pertama $\left(\mathrm{H}_{\mathrm{a}} 1\right)$ dinyatakan diterima bahwa disiplin kerja berpengaruh positif terhadap kinerja pegawai. Hal ini berdasarkan dengan hasil perhitungan uji $\mathrm{t}$ dimana telah diperoleh $\mathrm{t}_{\text {hitung }}$ sebesar 3.304 lebih besar dari nilai $\mathrm{t}_{\text {tabel }}$ sebesar 2.045. Jika nilai $\mathrm{t}_{\text {hitung }}$ lebih besar dari nilai $t_{\text {tabel }}$, maka $\mathrm{H}_{0} 1$ di tolak dan $\mathrm{H}_{\mathrm{a}} 1$ diterima.

Tingkat signifikansi variabel disiplin kerja sebesar 0,002 dimana 
tingkat signifikansi lebih rendah dari 0,05.

Sehingga dapat disimpulkan bahwa disiplin kerja berpengaruh positif dan signifikansi terhadap kinerja pegawai.

\section{Pengaruh Motivasi Kerja Terhadap} Kinerja Pegawai

Hasil pengujian hipotesis secara parsial motivasi kerja memiliki pengaruh terhadap kinerja pegawai, dan dapat dilihat pada rangkuman hasil pengujian dengan analisis uji $t$ (parsial) yang diuraikan dalam tabel 4.17 yang menunjukkan bahwa hipotesis kedua $\left(\mathrm{H}_{\mathrm{a}} 2\right)$ dinyatakan diterima bahwa disiplin kerja berpengaruh positif terhadap kinerja pegawai. Hal ini berdasarkan dengan hasil perhitungan uji t dimana telah diperoleh $t_{\text {hitung }}$ sebesar 2.713 lebih besar dari nilai $t_{\text {tabel }}$ sebesar 2.045. Jika nilai $t_{\text {hitung }}$ lebih besar dari nilai $\mathrm{t}_{\text {tabel }}$, maka $\mathrm{H}_{\mathrm{o}} 2$ di tolak dan $\mathrm{H}_{\mathrm{a}} 2$ diterima.

Tingkat signifikansi variabel disiplin kerja sebesar 0,011 dimana tingkat signifikansi lebih rendah dari 0,05. Sehingga dapat disimpulkan bahwa motivasi kerja berpengaruh positif dan signifikansi terhadap kinerja pegawai.

\section{Pengaruh Disiplin Kerja dan}

Motivasi Kerja Secara Bersamasama Terhadap Kinerja Pegawai

Hasil pengujian hipotesis secara simultan disiplin kerja dan motivasi kerja memiliki pengaruh terhadap kinerja pegawai, dan dapat dilihat pada rangkuman hasil pengujian dengan analisis uji f (simultan) yang diuraikan dalam tabel 4.18 yang menunjukkan bahwa hipotesis ketiga $\left(\mathrm{H}_{\mathrm{a}} 3\right)$ dinyatakan diterima bahwa disiplin kerja dan motivasi kerja secara silmultan berpengaruh positif terhadap kinerja pegawai. Hal ini berdasarkan dengan hasil perhitungan uji f dimana telah diperoleh $\mathrm{f}_{\text {hitung }}$ sebesar 5.876 lebih besar dari nilai $\mathrm{f}_{\text {tabel }}$ sebesar 3.328. Jika nilai $\mathrm{f}_{\text {hitung }}$ lebih besar dari nilai $\mathrm{f}_{\text {tabel }}$, maka $\mathrm{H}_{\mathrm{o}} 3$ di tolak dan $\mathrm{H}_{\mathrm{a}} 3$ diterima.

Tingkat signifikansi variabel disiplin kerja dan motivasi kerja terhadap kinerja pegawai sebesar 0,007 dimana tingkat signifikansi lebih rendah dari 0,05. Sehingga dapat disimpulkan bahwa disiplin kerja dan motivasi kerja secara silmultan berpengaruh positif dan signifikansi terhadap kinerja pegawai.

\section{KESIMPULAN}

a. Disiplin kerja berpengaruh positif dan signifikan terhadap kinerja pegawai pada SMK Tunas Jakasampurna. Apabila disiplin kerja yang dilakukan pegawai meningkat maka akan meningkatkan kinerja pegawai pada SMK Tunas Jakasampurna. Agar tingkat kinerja pegawai pada SMK Tunas Jakasampurna tetap baik, maka 
hendaknya variabel disiplin kerja harus diperhatikan dan ditingkatkan oleh pihak SMK Tunas Jakasampurna, indikatorindikator yang ada dalam disiplin kerja harus dipahami dan dijalankan oleh semua pegawai disekolah, sehingga semua peraturan dan kebijakan yang dibuat oleh manajemen sekolah dapat berfungsi dengan baik, tanpa membeda-bedakan antara staff dan manajemen.

b. Motivasi Kerja berpengaruh positif dan signifikan terhadap kinerja pegawai pada SMK Tunas Jakasampurna. Apabila motivasi kerja yang dilakukan pegawai meningkat maka akan meningkatkan kinerja pegawai pada SMK Tunas Jakasampurna. Agar tingkat kinerja pegawai pada SMK Tunas Jakasampurna tetap tinggi maka hendaknya variabel motivasi harus diperhatikan dan ditingkatkan oleh pihak SMK Tunas Jakasampurna, indikator-indikator yang ada dalam motivasi kerja harus dipahami dan dijalankan oleh semua pegawai sekolah. Motivasi kerja apabila dikelola dengan tepat, kontribusi positif terhadap terwujudnya kinerja pegawai akan mengalami perkembangan yang positif sehingga tujuan sekolah dapat dicapai. c. Disiplin kerja dan motivasi kerja secara bersama-sama berpengaruh positif dan signifikan terhadap kinerja pegawai pada SMK Tunas Jakasampurna. Apabila disiplin kerja dan motivasi kerja meningkat maka akan meningkatkan kinerja pegawai pada SMK Tunas Jakasampurna. Agar tingkat kinerja pegawai pada SMK Tunas Jakasampurna tetap tinggi maka hendaknya variabel dan indikatorindikator disiplin kerja dan motivasi kerja secara bersama-sama dan terintegrasi harus diperhatikan dan ditingkatkan serta dipahami oleh pihak SMK Tunas Jakasampurna, guna mendukung terciptanya kondisi sekolah yang diakui memiliki kinerja yang sangat baik oleh siswa, dapat menerapkan strategi pelayanan yang didukung sumber daya manusia yang handal dan penerapan teknologi yang update dan berkelanjutan sehingga pada akhirnya akan meningkatkan value pada sekolah.

\section{REFERENCES}

Astria, Kenny, 'Pengaruh Disiplin Kerja Dan Motivasi Terhadap Kinerja Karyawan Pada PT. Bank Rakyat Indonesia Cabang Pamulang', JURNAL MANDIRI: Ilmu 
Pengetahuan, Seni, Dan Teknologi, 2.1 (2018), 1-22

Busro, Muhammad, Teori-Teori Sumber
Prenadamedia Group, 2018

Rahman, Sarli, dkk, 'Pengaruh Motivasi, Kepuasan Kerja, Dan Disiplin Kerja Terhadap Kinerja Karyawan Sabrina City Hotel Pekanbaru', KURS, 2.2 (2017), 1-15

Sofiyanti, Neneng and Nawawi, Achmad, 'Pengaruh Disiplin Dan Motivasi

Kerja Terhadap Kinerja Pegawai

Satuan Polisi Pamong Praja

(Satpol) Kabupaten Karawang',

Buana Ilmu, 2.1 (2017), 1-23

Ajabar and Marina, Resi, 'Pengaruh Motivasi Kerja Dan Disiplin Kerja Terhadap Kinerja Guru SMA Negeri 1 Prabumulih', Jurnal Ilmiah MEA (Manajemen, Ekonomi \& Akuntansi), 3.2 (2019), 1-11

Mukminin, Lia Yuliana Amirul, Manajemen Sumber Daya Manusia Dalam Pendidikan, UNY Press, 2019

Marpaung, N. N. (2021a). Implementation of Online Learning Applications in SD Bina Kreasi Mandiri Bekasi : Infrastructure Effect Analysis. 2019(December 2019), 1796-1807. Marpaung, N. N. (2021b). Pengaruh Tingkat Pendidikan Terhadap
Kinerja Pegawai ( Studi Kasus

Disdukcapil Kota Bekasi ). 6(2), 8195.

Adamy, Marbawi, Manajemen Sumber Daya Manusia Teori, Praktik Dan Penelitian, Universitas

Malikussaleh, 2016

Kawiana, I Gede Putu, Manajemen Sumber Daya Manusia "MSDM" Perusahaan, 2020

Agung, Zarah Kurniawan \& Puspitaningtyas, Metode Penelitian Kuantitatif, Airlangga University Press, 2016.

Farisi, Salman, dkk, 'Pengaruh Motivasi

Dan Disiplin Kerja Terhadap Kinerja Karyawan’, Jurnal

Ranu, Saifu, 'Pengaruh Motivasi Kerja Dan Disiplin Kerja Terhadap Kinerja Pegawai Pada Dinas Tatakota Dan Perumahan Kota Semarang', Dharma Ekonomi, 44, 2016

Beno, Jose and Irawan, Dody Nata, 'Pengaruh Motivasi Kerja, Disiplin Kerja Dan Lingkungan Kerja Terhadap Kinerja Pegawai Pt. Penindo Ii Teluk Bayur Padang', Jurnal Sains Dan Teknologi Maritim, 20.1 (2019), 1-14 
JURNAL PARAMETER, Volume 7 No. 1, Februari 2022 Page. 41 - 56

ISSN Cetak : 1979-8865, ISSN Online : 2716-1676

Kurniawan, Agung Widhi and

Puspitaningtyas, Zarah, Metode

Penelitian Kuantitatif, 2016

Sari, Selvi Yona, 'Pengaruh Disiplin

Kerja, Lingkungan Kerja, Dan

Motivasi Kerja Terhadap Kinerja

Karyawan Pada PT Tigaraksa

Satria.Tbk Cabang Padang', Jurnal

EKOBISTEK, 6.1 (2017), 1-9

Tho'in, Muhammad, 'Effects of Training,

Work Discipline, and Motivation

Against Employee Performance at

Islamic Bank', Al-Tijary, 3.2

(2018), 131

Sari, Vivi Nila, dkk, 'Pengaruh Disiplin

Kerja, Motivasi Dan Kompensasi

Terhadap Kinerja Karywan Pt.

Kereta Api (Persero) Divisi

Regional Ii Sumatera Barat',

EKOBISTEK, 5.2 (2016), 1-9

Sinambela, Lijan Poltak, Manajemen

Sumber Daya Manusia Membangun

Kerja Yang Solid Untuk

Meningkatkan Kinerja, 2016

Abdulah, Budiman, 'Pengaruh Motivasi

Dan Disiplin Kerja Terhadap

Kinerja Karyawan Smk Ksatrya

Jakarta', Jurnal Ekonomi:

Ekonomi, Bisnis \& Manajemen, 9.1

(2018), 1-16

Hertati, Diana, Manajemen Sumber Daya Manusia, Mitra Sumber Rezeki, 2020 